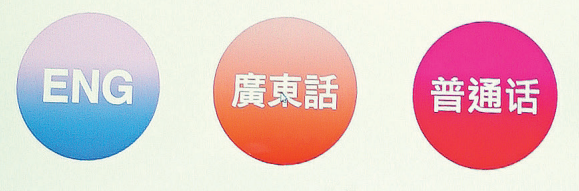

\title{
Future Robot
}

Contributor: Eli Blevis

(1) Curator/Editor: Eli Blevis

$\rightarrow$ Genre: Human-robot interaction (HRI)

DOI: $10.1145 / 2856122$

(C) 2016 ACM 1072-5520/16/01 $\$ 15.00$
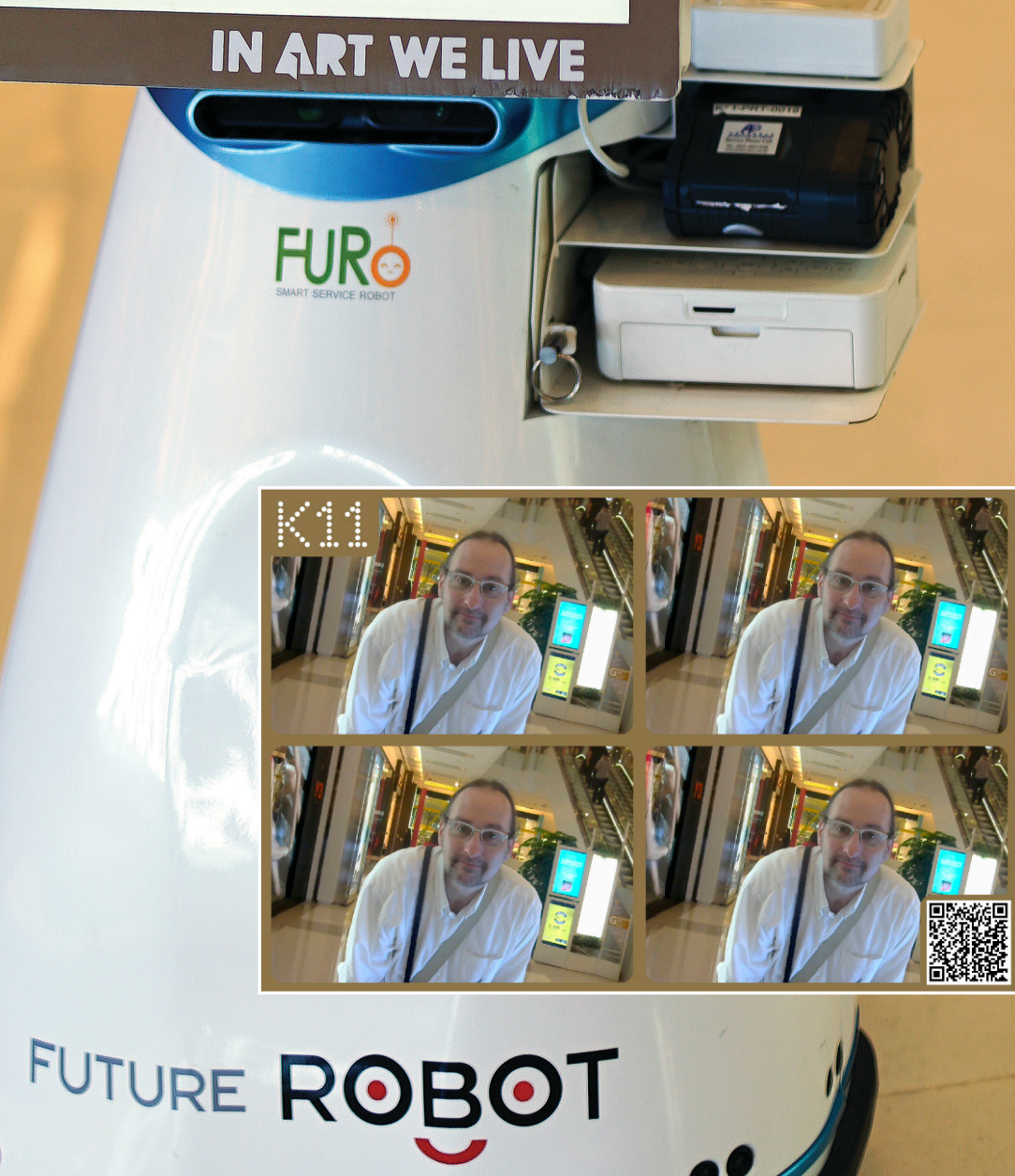